\title{
GEOLOGY
}

UDC 553.041

Ye.V.Duzhnikova, orcid.org/0000-0003-0630-6273,

T.V. Kryazheva, Cand. Sc. (Geol.-Min.), orcid.org/0000-0003-2804-020X,

K. Ye. Toleubek, orcid.org/0000-0003-2126-8084 https://doi.org/10.33271/nvngu/2020-3/005

Karaganda State Technical University, Karaganda, the Republic of Kazakhstan, e-mail: dizarika1@gmail.com

\section{KOKTASZHAL ORE FIELD (CENTRAL KAZAKHSTAN) RESEARCH RESULTS}

Purpose. Predictive assessment of promising mineralization points and ore occurrences of copper, gold, silver and associated components at the Koktaszhal ore field.

Methodology. Analysis of literary and library materials. Reconnaissance routes to study the geological situation of the area. During the passage of the routes, samples were taken, their mineralogical study was carried out to determine the patterns of distribution of the main ore minerals and impurities. To determine the contents of useful components, phase chemical analysis, spectral analysis, and spectrographic aurometric analysis were used.

Findings. The materials and their analysis obtained as a result of research significantly expand the idea of the ore field under study. The main ore-forming minerals are chalcopyrite and bornite, in much smaller amounts chalcosine, pyrite, and molybdenite are present in the ores. The main oxidized copper minerals in decreasing order are malachite, chrysocolla, chalcanthite, azurite. Thanks to detailed geological, mineralogical, petrographic, and laboratory studies, promising copper-porphyry ore occurrences have been identified. The aureole patterns are spatially combined and drawn up with the mapping of mineral concentrations on them, which are recommended to be studied in more detail.

Originality. According to the results of the research and analysis, new promising points of mineralization and metallizing process were identified using the latest high-precision methods for studying ore-forming minerals of copper-porphyry deposits.

Practical value. Studying the mineralogy of the ore field allows determining the typomorphic features of minerals for the search and evaluation of mineral deposits as well as improvement of the complexity of the use of raw materials. The use of mineralogical research methods at the current level increases the efficiency of exploration, helps to search for new promising areas and deposits and, in general, increases the mineral resource base of Kazakhstan, which is one of the most important tasks of developing countries. The results of the studies can serve as the basis for the subsequent further study of the ore field, quantitative assessment of the prospects of resources, the choice of mining and beneficiation methods. The additional study of little-known copper-porphyry ore occurrences, the search for new deposits of copper, gold, silver and associated components are the primary task of their industrial development in modern technologies.

Keywords: Koktaszhal ore field, copper-porphyry mineralization, mineralogical zoning, Central Kazakhstan

Introduction. Search and exploration of new deposits are the basis for replenishing the mineral resource base of Kazakhstan. Porphyry copper deposits are the main sources of not only copper but also gold, silver, molybdenum and a number of rare metals [1].

In connection with increasing the world prices for metals, the interest has arisen in the objects of the Spassk zone, where currently, on its eastern extension, prospecting sections of the Koktaszal ore field are under exploration. Studying the stone material allows determining the zoning of ore occurrences of the Koktaszhal ore zone, determining the composition and age of intrusive rocks and ore mineralization, and assessing the conditions for the formation of ore occurrences [2].

The Koktaszhal ore field is located in the north-eastern part of the Karaganda region of the Republic of Kazakhstan and is administratively located north-west of the settlement of Egendybulak. Geologically, the Koktaszhal ore field is a part of the Spassk metallogenic zone, stretching far beyond the boundaries of the area studied.

The ore field is represented by northwest ridges with outcrops of ore-localizing plagiogranite-porphyry intrusion. The

(c) Duzhnikova Ye. V., Kryazheva T.V., Toleubek K. Ye., 2020 hills quickly turn into hollows of various directions, forming saddle-shaped relief shapes. Separate hills are dotted with large blocks and have rocky steep slopes [3].

Studying the Koktaszhal ore field allows identifying promising new ore areas to replenish the mineral resource of the Karaganda region.

Literature review. Geological exploration of the Koktaszhal deposit in the adjacent territories (Koktaszhal ore field) was carried out in three stages: the end of the $19^{\text {th }}$ and the beginning of the $20^{\text {th }}$ centuries: regional geological-geographical, ethnographic studies, penetration of single investigators; until the 50 s of the $20^{\text {th }}$ century: regional studies with revisions of famous copper manifestations, and then in the 50-90s: systematic state surveys and searches. In 1995-1999 the Altyn Mager Company JV discovers new zones on the flanks of the Koktaszhal ore-bearing structure. The works covered the area of $250 \mathrm{~km}^{2}$ and consisted of surface mapping, mining and drilling operations. The mapping of the area was carried out by walking routes and in the closed areas by advancing forty small holes and 125 wells (1355.3 running meters). At the Koktaszhal deposit $\left(12.6 \mathrm{~km}^{2}\right)$, magnetic exploration was carried out in the $20 \times 5 \mathrm{~m}$ network, lithogeochemical and spectrographic aurometric surveys in the $100 \times 20 \mathrm{~m}$ network; exploratory 
ditches and wells were made to revise the central part and to study the flanks. A total of 13 wells were drilled with the volume of $4761.2 \mathrm{~m}$. As a result of these works, the area of $175 \mathrm{~km}^{2}$ was recognized as promising. In 2010-2011, the Altai Polymetals LLP summarized and analyzed all the materials from previous years and concluded that the exploration of the Koktaszhal ore field corresponded to the stage of prospecting and appraisal work $[4,5]$. Since 2013, the field and the adjacent contract area have been explored by the Altai Polymetals LLP.

The analysis of the results of exploration work carried out within the ore field allows concluding that the prospects for identifying ore bodies for depth and area are far from being exhausted $[5,6]$.

Unsolved aspects of the problem. The ore bodies outcropping to the day surface were studied by exploratory ditches. In different years, 55 ditches were covered in the Koktaszhal deposit area, 8 ditches in the Zharykty section, 5 ditches in the Keregetas section, with the total volume of 2325,846 and $650 \mathrm{~m}^{3}$, respectively. At the Koktaszhal deposit, ditches were crossed across the strike of ore deposits approximately every $50-100 \mathrm{~m}$. All of them opened ore bodies for the full thickness with an on-board copper content of $0.5 \%$, most of the sections at the side of $0.2 \%$ and only a small part of the anomalies (30\%) with contouring of $0.1 \%$. An extensive aureole of copper tracing the main deposits with a single ditch has not been opened for the full thickness; the workings have passed its axial part and require elongation in the northeast and southwest directions [7]. The other numerous aureoles, zones of mineralization and polarizability of the rocks in the considered area of the Koktaszhal ore field $\left(175 \mathrm{~km}^{2}\right)$ were opened fragmentarily, that is, they are practically not studied.

Purpose. Exploring poorly studied promising ore occurrences of the Koktaszhal ore field and identifying new mineralization points.

Methods. In the course of the work, 27 ditches were completed, 573 samples were taken with the interval of $2 \mathrm{~m}$, which made it possible to identify new manifestations with an increased content of useful components in them. Mineralogical and petrographic studies were carried out using an Altami POLAR 312 polarizing microscope. Mineralogical studies of oxidized primary and secondary copper sulfides were carried out in briquette sections using an OLYMPUSBX 51 Pol. microscope, SIMAGIS 2P-2C video camera and SIAMS Mineral C7 image analysis software. Studying the total sample was carried out on a D8ADVANCE diffractometer. Chemical analysis and spectrographic aurometric analysis were carried out in the laboratory of the Centrgeolanalit LLP. A map of promising mineralization points was compiled using the MapInfo program.

Results. Mineralogical and petrographic studies have shown that the mineralogy of primary sulfide ore deposits is fairly simple. The main ore-forming minerals are chalcopyrite and bornite; in much smaller quantities chalcosine, faded ore, pyrite, molybdenite, and others are present in the ores [8]. The main oxidized copper minerals in decreasing order are malachite, chrysocolla, chalcanthite, and azurite.

Malachite is noted in the form of films, crusts, in interlayers with chrysocolla, inclusions in quartz measuring $0.05-$ $0.1 \mathrm{~mm}$ to $0.5-1.0 \mathrm{~mm}$. The thickness of the layers of malachite is $0.05-0.10 \mathrm{~mm}$, the size is $0.1-0.25-1.0 \mathrm{~mm}$.

Chrysocolla forms veins, often with malachite, crusts, films with the thickness of $0.05-0.05 \times 0.5 \mathrm{~mm}$, inclusions in quartz of $0.05-0.25 \times 0.5 \mathrm{~mm}$.

Chalcanthite is found in fragments of $0.5-1.0 \mathrm{~mm}$, inclusions in quartz of $0.1-0.3-0.3-0.5 \mathrm{~mm}$, in the form of streaks, crusts of $0.025-0.1-0.1-0,5-0.025 \times 0.5 \mathrm{~mm}$.

Azurite is rarely found in the form of films on quartz fragments of $0.05-0.025 \times 0.2 \mathrm{~mm}$, in the form of inclusions in a micaceous fragment of $0.025-0.05 \mathrm{~mm}$ in size.

Using the results of the phase chemical analysis for the content of copper compounds (Table 1) and the results of mineralogical analyzes of briquette sections, the content of copper minerals in the initial ore was determined. The results are shown in Table 2.

Primary copper sulfides are represented by chalcopyrite, and secondary ones are bornite, chalcosine, and covellite.

Non-metallic minerals are mainly represented by quartz, albite of the composition $\mathrm{NaAlSi}_{3} \mathrm{O}_{8}$, clinochlorine $\mathrm{Mg}_{5} \mathrm{Al}\left(\mathrm{Si}_{3} \mathrm{Al}\right) \mathrm{O}_{10}(\mathrm{OH})_{8}$, muscovite $\mathrm{K}_{2} \mathrm{O} \times 3 \mathrm{Al}_{2} \mathrm{O}_{3} \times 6 \mathrm{SiO}_{2} \times$ $\times 2 \mathrm{H}_{2} \mathrm{O}$. Due to a low content of ore components, the X-ray diffractometric method cannot determine them. The enclosing rocks are saturated with iron hydroxides, largely sericitized, covered with a thin network of microcracks, to which there are confined thin inclusions of ore minerals, including grains of free gold, magnetite, goethite, hematite and rutile.

Chalcopyrite in the ore field is the main, most common ore-forming mineral. The distribution area of chalcopyrite is much larger than the area of ore bodies. While industrial impregnation of chalcopyrite is widespread throughout the ore field, auroles of distribution of other ore minerals (bornite, chalcosine, fahl ore, molybdenite) are enclosed within the aureole of chalcopyrite. Usually, chalcopyrite, together with other sulfides, is developed in veins with non-metallic minerals and in their nesting clusters; somewhat less often, chalcopyrite develops directly in the host rocks [6, 8]. In veins, chalcopyrite forms nesting clusters and growths in the vein material, often connected by thin conductors passing along the grain boundaries of vein minerals (Fig. 1). Often, chalcopyrite emissions are confined to the selvages of the veins, but along with this, chalcopyrite is also found in the central part of the veins. Directly in the rock, chalcopyrite forms open scattered impregnation, perforations, less often nest-shaped clusters.

Table 1

Results of phase chemical analysis of the initial ore

\begin{tabular}{|c|c|c|}
\hline \multirow{2}{*}{ Compound types } & \multicolumn{2}{|c|}{ Ore } \\
\cline { 2 - 3 } & $\begin{array}{c}\text { Absolute } \\
\text { content, } \%\end{array}$ & $\begin{array}{c}\text { Relative } \\
\text { content, } \%\end{array}$ \\
\hline Copper - sulfates - Chalcanthite & 0.09 & 18.4 \\
\hline $\begin{array}{c}\text { - oxides: malachite, azurite, } \\
\text { chrysocolla }\end{array}$ & 0.35 & 71.4 \\
\hline - secondary sulfides & 0.04 & 8.2 \\
\hline - primary sulfides & 0.01 & 2.0 \\
\hline In total & 0.49 & 100 \\
\hline Zinc - sulfates & $<0.05$ & - \\
\hline - oxides & $<0.05$ & - \\
\hline - sulfides & $<0.05$ & - \\
\hline In total & 0.05 & - \\
\hline
\end{tabular}

Table 2

Ore minerals content in ore

\begin{tabular}{|l|c|c|c|}
\hline Mineral name & $\begin{array}{c}\text { Absolute } \\
\text { content } \\
\text { associated with } \\
\text { this mineral, \% }\end{array}$ & $\begin{array}{c}\text { Copper content } \\
\text { in monomineral } \\
\text { fraction, \% }\end{array}$ & $\begin{array}{c}\text { Ore } \\
\text { minerals } \\
\text { content } \\
\text { in ore, \% }\end{array}$ \\
\hline Malachite & 0.21 & 57.4 & 0.40 \\
\hline Chrysocolla & 0.10 & 20.0 & 0.50 \\
\hline Chalcanthite & 0.09 & 25.0 & 0.36 \\
\hline Azurite & 0.04 & 55.3 & 0.10 \\
\hline Secondary sulfides & 0.04 & 60.0 & 0.07 \\
\hline Chalcopyrite & 0.01 & 34.0 & 0.03 \\
\hline Total & 0.49 & - & 1.46 \\
\hline
\end{tabular}



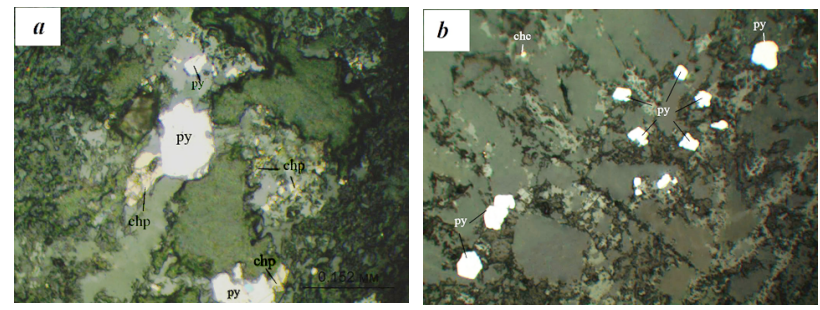

Fig. 1. Chalcopyrite in the form of xenomorphic aggregates ( $a$, b). Sections, 10X magnification with analyzer (chp - chalcopyrite; py-pyrite)

The size of chalcopyrite effusions varies widely, from 0.006 $\mathrm{mm}$ to $3 \mathrm{~cm}$. The most common formations of this mineral are hundreds and tenths of a millimeter in size.

Under the microscope, a distinct association of chalcopyrite to the areas of elevated cataclase is observed. More or less uniform impregnation develops in altered plagio-granitporphyries; in mineralized porphyrites and tuffs, chalcopyrite effusions mainly in veins along with non-metallic minerals and other sulfides.

Chalcopyrite is found in association with pyrite, bornite, faded ore, chalcosine, molybdenite, magnetite and hematite. Such non-metallic minerals as quartz, calcite, epidote, chlorite, garnet, albite, and sericite are found together with it.

The relationship of chalcopyrite with pyrite in all cases of their joint presence indicates a later, relative to pyrite, effusion of chalcopyrite. Chalcopyrite is overgrown with pyrite effusions, penetrates through cracks, corroding pyrite. Very often, chalcopyrite forms small ingrowths in pyrite.

Bornite is also the main ore-forming mineral, following the prevalence of chalcopyrite. Developing with the latter, it forms streaky and vein-streaky boron-chalcopyrite ores widespread in the ore field.

Three kinds of relationships between chalcopyrite and bornite were observed.

1. The accretions of chalcopyrite with bornite are very widespread. In all cases without exception, the boundaries between these minerals in the ingrowths are even, they are straight or, more often, smooth curved lines, without traces of corrosion of one mineral by the other. Such relationships are considered a sign of simultaneous formation of minerals and are characterized as a structure of mutual boundaries.

2. Chalcopyrite with bornite forms a gating structure of the solid solution decomposition. In this case, chalcopyrite either forms very thin, measured by microns, intersecting plates in bornite, or effuses as coarser plates, clearly wedging out at the intersections.

3. Chalcopyrite forms thin $(0.005 \mathrm{~mm})$ rims around the bornite, from which spear-shaped plates extend into the bornite effusion.

Sometimes chalcopyrite, in addition to the formation of rims, effuses in the bornite along the cracks. Such structures indicate the development of hypogenic substitution of bornite with chalcopyrite.

At the same time, in a number of cases, edge chalcopyrite rims around bornite are observed, the formation of which is probably associated with decomposition of the solid solution (chalcobornite) with subsequent coalescence and displacement of chalcopyrite to the peripheral part. In the process of hypergenic changes in ores, bornite is replaced by chalcosine.

Based on spectral analysis, impurities of lead, silver (the latter is present in much larger amounts than in chalcopyrite hundredths of a percent), bismuth, manganese and titanium are established in bornite. Antimony, arsenic, and zinc were found in separate samples.

Pyrite takes the third place, after chalcopyrite and bornite, in terms of prevalence among ore minerals. In the areas relatively enriched with copper minerals, pyrite is usually present either in relatively small amounts or completely absent. But in essentially sericitic rocks, quartz-quartz, quartz-sericite and quartz-chlorite-sericite schists, pyrite is the predominant, and often the only ore mineral. In these rocks, pyrite forms either fine dust-like impregnation (Figs. 2, $a, b, c$ ), or rather thick impregnation to streaks of solid pyrite (Fig. 2, d), in which the content of this mineral reaches $70 \%$ of the vein volume. The thickness of the veins does not exceed $3-5 \mathrm{~cm}$. Much less often, pyritization develops in quartz-chlorite and chloritequartz rocks [8].

Pyrite is mainly confined to the bands relatively enriched in quartz, while strips of sericite, chlorite-sericite, and chlorite composition contain its individual grains. The size of pyrite effusions varies widely (from 0.03 to $5-6 \mathrm{~mm}$ ), but the size of individual grains is more or less constant $(0.03-0.05 \mathrm{~mm})$. A characteristic feature of the described pyrite difference is the shape of its grains. They are square, rectangular, triangular, less often lenticular "shuttles". In this case, the elongated grains are located with the elongated side along the schistosity of the rock.

Square, triangular and rectangular pyrite grains and their shape are single crystals, usually non-zonal.

In some cases, relic zonality of growth is found in them. With a significant pyrite content in the rocks, it forms relatively large, up to $5 \mathrm{~mm}$, spots, which in the outer part retain the crystallographic outlines inherent in pyrite. In some cases, recrystallization with enlargement of grain occurs in these formations.

In schists, pyrite crystals are overgrown with stalked quartz or a thin discontinuous calcite rim, and then stalked quartz. The quartz rim in the "pressure shadows" reaches its maximum width, while in directions close to normal to the shale of the rocks, it has much less power, or completely absent.

Chalcosine is found in $20 \%$ of the sections examined, but always in negligible amounts. Undoubtedly, hypogenic chalcosine is found at depths from 100 to $365 \mathrm{~m}$, in the paragenesis with completely unchanged primary copper sulfides: chalcopyrite and bornite. At the same time, ores, bornite-chalcopyrite, not containing chalcosine, were crossed above the wells. This fact, as well as the considerable depths at which chalcosine occurs, the complete absence of any secondary, hypergenic minerals in the paragenesis caused chalcosine to be classified as a group of hypogenic minerals. This was confirmed by the structural relationship of chalcosine with bornite. Chalcosine is very closely associated with the latter. In ores, chalcosine is present exclusively in the halos of the development of bornite. It can be said that where there is no boron, there is
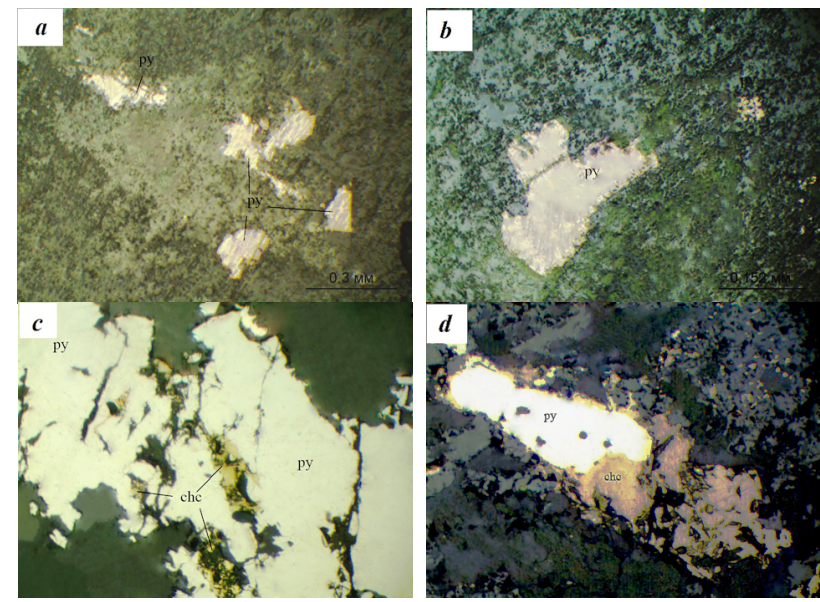

Fig. 2. Pyrite in the form of isometric grains, polished sections, $10 X$ magnification with analyzer (a). Pyrite in the form of idiomorphic, hipidiomorphic grains $(b, c)$ and prismatic crystals $(d)$. Polished sections, 20X magnification with analyzer (chp-chalcopyrite; py - pyrite) 
probably no hypogenic chalcosine. In those areas of ore bodies where chalcosine is found, a relatively high copper content is usually observed. In the ores studied, chalcosine was observed only under a microscope.

Fahl ore is rare. The content of fahl ore in the ore field is negligible. Fahl ore is found in quartz veins in altered plagiogranite porphyries, where it forms thin phenocrysts and nesting clusters, reaching in some cases $7-8 \mathrm{~mm}$. Fahl ore was also found in a quartz vein with chlorite II. In addition, in some cases, fahl ore, together with copper sulfides, was deposited directly in the rocks along microcracks. In these cases, its presence is established only under a microscope.

Molybdenite is a mineral that is quite common in the ore field but it does not form any significant clusters. In industrial copper ores and in areas of mineralization, molybdenite is not evenly distributed. There are areas that are relatively enriched in molybdenite [8].

Molybdenite is found in quartz and calcite-quartz veins, less often it is developed in altered rocks and only in isolated cases was it found in veins of sericite-quartz, chlorite-quartz and epidote-calcite-quartz composition. Among the vein minerals, molybdenite effuses either in the form of winding discontinuous veins, or in the form of chains of plates, or in individual phenocrysts. Sometimes there are nest-shaped, rosette-like accumulations of molybdenite plates. There are frequent cases of predominant concentration of molybdenite in the nearband portion of the veins. In rocks, molybdenite is confined to microcracks or to sites of development of sericite and chlorite. It is either a chain of scales or sporadic phenocrysts.

The size of molybdenite effusions ranges from hundredths of a millimeter to $2 \mathrm{~mm}$. A characteristic shape of the molybdenite effusion is plates, the length of which is $3-4$ times their width. The plates are usually somewhat curved.

By the time of formation, molybdenite is distinctly later than vein minerals: quartz, chlorite, and sericite. Of the ore minerals, chalcopyrite, pyrite, and bornite were found along with molybdenite. The molybdenite-chalcopyrite association is extremely characteristic; less commonly, molybdenite occurs with pyrite and, in rare cases, with bornite, and only with chalcopyrite does it sometimes form intergrowths. Chalcopyrite corrodes molybdenite, especially often corrosion phenomena develop at the ends of the plates, which in turn acquire a lath-like appearance.

Magnetite. In the ore field, there is a certain confinement of magnetite to chlorite-bearing rocks: chloritized and epidotized porphyrites, quartz-chlorite rocks and quartz-chlorite schists, for which it is only very possible to establish the source rock. Magnetite is much less common in altered plagiogranite porphyry.

Two generations of magnetite are distinguished. Magnetite I includes magnetite scattered in the form of small (0.05$0.1 \mathrm{~mm}$ ) grains in chlorite-bearing rocks, as well as relic magnetite observed in hematite and chlorite-hematite veins. The shape of magnetite grains is euhedral, less often isometric. The described generation of magnetite is subjected to martitization. The most common replacement of magnetite is hematite from the periphery of the grains to the center. In this case, the usual structures of the border edges and the lattice structure are formed. Together with sulfides, magnetite I is very rare. In all cases of the presence of magnetite, together with hematite and chlorite, it forms streaky clusters, on the periphery of which sulfides develop: bornite and chalcopyrite. The latter corrode both magnetite and replacement hematite.

Magnetite II is developed in quartz and calcite-quartz veins in association with sulfides: chalcopyrite, bornite and pyrite, as well as in hematite veins with sulfides. In quartz and quartz-carbonate veins, magnetite forms small insulated phenocrysts of isometric shape, and sometimes rounded inclusions in chalcopyrite and born. zation.

Unlike magnetite I, magnetite II does not undergo martiti-
Hematite. Like magnetite, hematite is present almost exclusively in substantially chlorite rocks. It is as spread as magnetite, with which hematite forms a close bond (Fig. 3).

Two types of hematite are distinguished in the ore field.

1. Martite develops along magnetite I with the formation of substitution structures: edge and ethmoid rims. It is detected only under a microscope.

Considerable depths, at which martitization is manifested (up to $400 \mathrm{~m}$ and more), as well as the absence of any hypergenic minerals in association with martite, indicate that the process of martitization of magnetite took place under hypogenic conditions.

2. Hematite of the second variety is allocated in veins and veinlet clusters together with quartz or chlorite, or forms veins with magnetite II and sulfides.

Hematite is one of the earliest minerals in the ore process, previously precipitated by calcite, magnetite II and sulfides. Hematite-quartz veins are split by veins of calcite and are corroded by it. Hematite forms extremely thin (up to $0.01 \mathrm{~mm}$ ) plates in the mass of quartz.

In vein-like deposits, together with chlorite, hematite forms a tangled felt of small plates. In one case, rare hematite flakes are found in chlorite, which forms winding veins in vein quartz. Hematite plates are often strongly bent. In some cases, muschketowization of hematite was observed.

In the zone of hypergenesis, hematite is quite stable. Even in the samples taken on the surface, streaks of lamellar hematite were found in which malachite develops between the lamellae and along the secant cracks. Under the microscope, hematite was replaced by hydrogetite.

In single samples, xenomorphic grains of iron hydroxides (goethite, limonite) are observed.

After mineralogical and petrographic studies and determination of mineralogical zoning, chemical and spectral analyzes, spectrographic aurometric analysis was carried out. Based on the conducted studies, the patterns of promising areas with average percentages of minerals were compiled.

The ore field is represented by the industrial Koktaszhal copper-porphyry deposit, ore occurrences of copper, polymetallic-copper and gold-copper mineralization: Zharykty, Yuzhnoye, Severo-Agyzskoye, Koktaszhal Southeast II and I, Keregetas and a number of unnamed mineralization points. Most of them are poorly studied. Being the most studied, the Koktaszhal deposit is considered as a standard for the abovedescribed ore occurrences in this part of the mineralogenic zone [9].

Below there is a brief description of the most promising ore occurrences, spatially grouped into several sections.

The Qquartz-vein zone (Fig. 4) is located near the northern frame of the contract territory and is represented by a dense network of subparallel quartz, barite and quartz-barite meridional veins located in granites and granite porphyry carbon. It is characterized by minor manifestations and mineralization points of copper [9].

Manifestations 1, 2. In the silicified and epidotized dikes of diorites occurring in plagiogranites of the Lower Carbonifer-
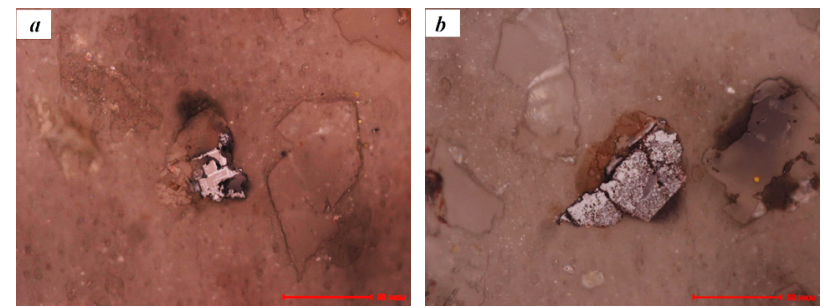

Fig. 3. Hematite with magnetite bond in samples:

a- magnetite in quartz with decay into hematite plates (blue), polished section, magnification 500X); $b$ - magnetite replacement with hematite, polished section, magnification $500 \mathrm{X}$ 


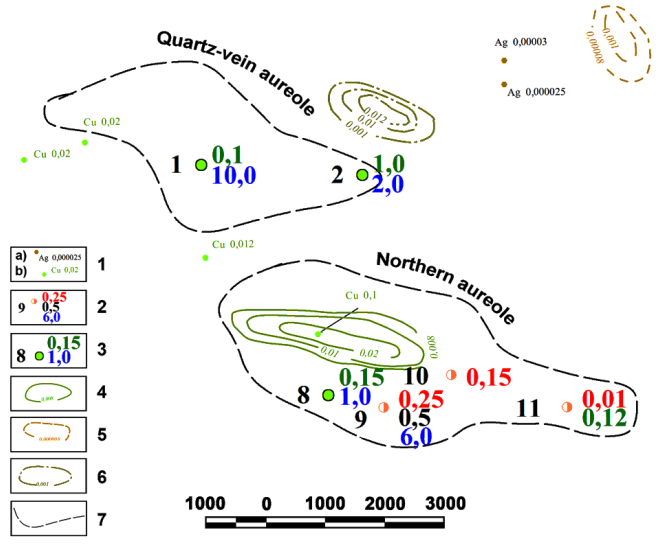

Fig. 4. The pattern of the Quartz-vein and Northern aureoles:

1 - samples with the maximum element content; 2 - gold ore occurrence: the figure on the left is the number, the figure on the right is the content: red - gold $(g / t)$, green - copper (\%), blue - silver $(\mathrm{g} / \mathrm{t})$, black - lead (\%); 3 - the same, copper; 4 - isoconcentration of copper (\%) in loose deposits; 5 - silver isoconcentration (\%) in loose deposits; 6 - nickel isoconcentration (\%) in loose deposits; 7 - contour of the aureoles

ous, copper contents of up to $0.4-1.05$ and silver content of $2.0-10.0 \mathrm{~g} / \mathrm{t}$ were revealed [2].

Northern aureoles (Fig. 4) are located north-northwest of the Koktaszhal deposit, 2-5 km between the mentioned deposit and the Quartz-vein zone and are confined to discontinuous structures among granodiorites [10].

Manifestations 8, 9. The quartz vein, distinct, is traced by scattered fragments for $400 \mathrm{~m}$, lies in granodiorites of the Lower Carboniferous. The content of copper in quartz is up to $0.15-0.5 \%$ and silver content is up to $1.0-6.0 \mathrm{~g} / \mathrm{t}$ and that of gold is up to $0.25 \mathrm{~g} / \mathrm{t}$.

Manifestation 10. Fine-grained silicification of granodiorites; according to the spectral analysis of grab samples, the gold content is up to $1.5 \mathrm{~g} / \mathrm{t}$.

Manifestation 11. Copper mineralization in the form of crusts and smears of malachite along cracks and nests of up to $0.5 \mathrm{~cm}$ in veins of quartz with epidote and oxidized pyrite among intensely quartz and epidotized granodiorites of lower carbon. The copper content is $0.12 \%$; gold $-0.01 \mathrm{~g} / \mathrm{t}$ (spectral analysis of grab samples).

North-Agyz ore occurrence. It is located to the north-northwest of the Keregetas section outside the contract area. Mineralization is represented by impurities and thin veins of malachite and azurite, plaque of copper black, developed in the zone of schist and hydrothermal alteration of the Lower Devonian andesite porphyrites [10]. The length of the ore zone is $200 \mathrm{~m}$, and the apparent thickness is $5-6 \mathrm{~m}$. The copper content is up to $0.38 \%$; of lead $-0.02 \%$ and silver $-1.5 \mathrm{~g} / \mathrm{t}$. It was opened by single ditches.

The Western aureoles (Fig. 5) are located 2-5 km southwest of the Zharykty section and are represented by lead-zinccopper with gold manifestations and points of mineralization. They are confined to the Ordovician volcanic-sedimentary deposits, broken through the granodiorites of the Carboniferous.

Manifestation 4. Ore mineralization in Ordovician porphyrites and plagiogranite-porphyry dikes breaking through them. Mineralization is confined to the sub-latitudinal zone of intense silicification and limonitization [10] with the length of $500 \mathrm{~m}$, visible thickness of 10-40 m, accompanied by a secondary aureole of copper with the intensity of $0.02 \%$ and the airspace anomaly of up to $7.0 \%$.

Spectral analysis of furrow and core samples showed the content of copper $0.05-0.3 \%$; molybdenum - up to $0.02 \%$; zinc - up to $0.04 \%$; gold $-0.01-0.02 \mathrm{~g} / \mathrm{t}$. A ditch and a well have been completed.

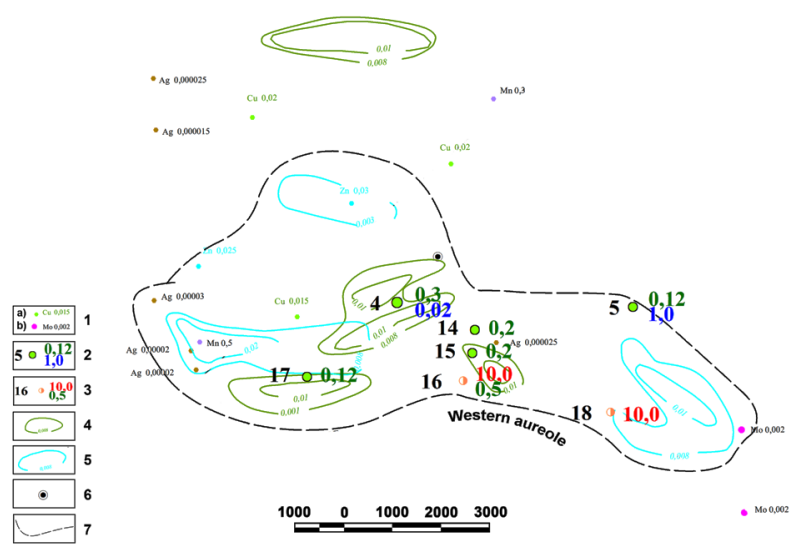

Fig. 5. The pattern of the West aureoles:

1 - samples with the maximum element content; 2 - gold ore occurrence: the figure on the left is the number, the figure on the right is the content: red - gold $(g / t)$, green - copper $(\%)$, blue - silver $(g / t) ; 3$ - also, copper; 4 - isoconcentration of copper (\%) in loose deposits; 5 - zinc isoconcentration (\%) in loose deposits; 6-point with hypergenic copper mineralization (malachite, chrysocolla, azurite); 7 - contour of the aureoles

Manifestations 5. Quartz streaks with the thickness of $3-5 \mathrm{~cm}$ are in silicified porphyrites of Ordovician, in quartz and enclosing rocks there are greases of malachite, pyrite and hematite. Copper content is up to $0.12 \%$; silver - up to $1.0 \mathrm{~g} / \mathrm{t}$.

Manifestations 14, 15. Ore occurrence is represented by smears of malachite along cracks in the epidotized tuffs of Ordovician andesites. Spectral analysis of the ore samples established the copper content of $0.2-0.8 \%$.

Manifestation 16. In the sheeted and silicified tuff sandstones of the Middle Devonian Khandar Formation, the copper content of $0.5 \%$ was determined by spectral analysis of ore samples, and the gold content in vein quartz by gold spectrometry analysis - to $0.03-10.0 \mathrm{~g} / \mathrm{t}$. It was opened by a single ditch. Sheeted silicified and epidotized porphyrites are with smears of malachite with the thickness of $2.0 \mathrm{~m}$, copper content is up to $0.15 \%$. The parameters of the hydrothermal rock zone and silicification zones have not been determined.

Manifestation 17. Malachite smears are in hydrothermally altered andesite porphyrites of Ordovician. The copper content in the ore samples is $0.05-0.12 \%$.

Manifestation 18. In the tuff sandstone chordovica, penetrated by thin veins of quartz, a gold content of up to $10.0 \mathrm{~g} / \mathrm{t}$ was determined by spectrographic aurometric analysis of quartz ore samples. The thickness of the silicification zone is $0.5 \mathrm{~m}$; the strike zone is not traced.

The Zharykty-Koktaszhal Northern aureoles (Fig. 6) are located in the same ore-bearing zone between the Koktaszhal deposit and the Zharykty section in the exocontact of granitegranodiorite intrusion among the volcanic-sedimentary stratum of andesite composition with intercalations of limestone, sandstone, tuff and tuffite [9].

Manifestations 6, 7. Quartz veins with the thickness of 3$5 \mathrm{~cm}$ are in silicified porphyrites of Ordovician, in quartz and enclosing rocks there are impurities of malachite, pyrite and hematite. Copper content is up to $0.15-0.5 \%$; silver - up to $4.0-60.0 \mathrm{~g} / \mathrm{t}$; lead - up to $0.8-1.0 \%$.

Manifestation 26. The zone of schist and silicification of granodiorites with the length of $100 \mathrm{~m}$ with the apparent thickness of $1-3 \mathrm{~m}$ is characterized by the presence of malachite along the cracks. According to the results of spectral analysis of furrow samples, the copper content is $0.1-1.0 \%$; gold $0.01-0.04 \%$.

The North Keregetas aureoles (Fig. 7) are located directly north of the Keregetas section, beyond the contour of the contract area and are confined to the Devonian sedimentary stratum. 


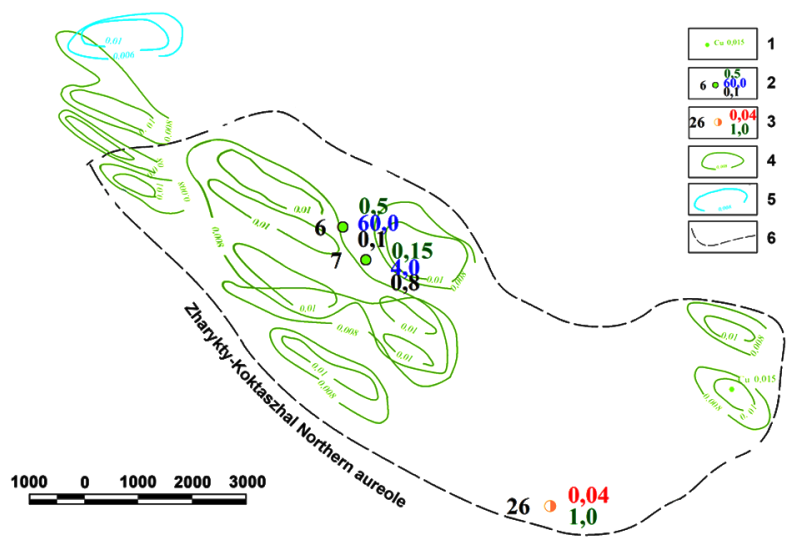

Fig. 6. The pattern of the Zharykty-Koktaszhal North aureoles: 1 - samples with the maximum element content; 2 - gold ore occurrence: the figure on the left is the number, the figure on the right is the content: red - gold $(\mathrm{g} / \mathrm{t})$, green - copper (\%), blue - silver $(\mathrm{g} / \mathrm{t})$, black - lead (\%); 3 - the same, copper; 4 - isoconcentration of copper (\%) in loose deposits; 5 - zinc isoconcentration (\%) in loose deposits; 6 - contour of the aureoles

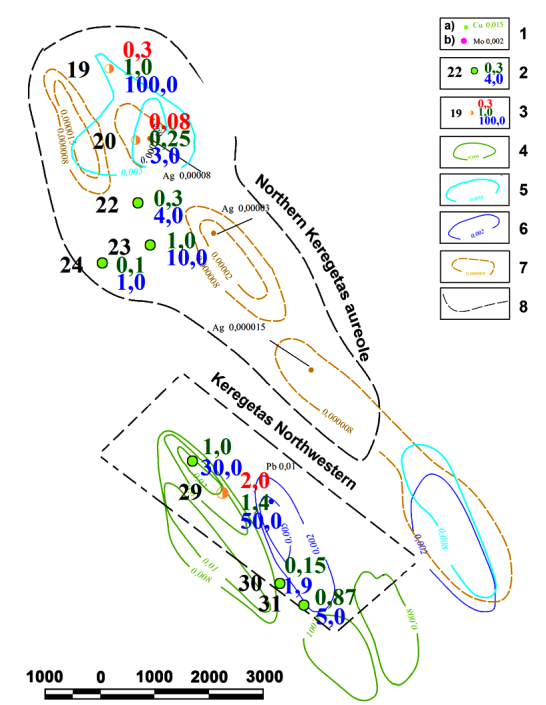

Fig. 7. The pattern of the Northern Keregetas aureoles and Northwestern Keregetas:

1 - samples with the maximum element content; 2 - gold ore occurrence: the figure on the left is the number, the figure on the right is the content: red - gold $(g / t)$, green - copper (\%), blue - silver $(\mathrm{g} / \mathrm{t}) ; 3$ - the same, copper; 4 - isoconcentration of copper $(\%)$ in loose deposits; 5 - zinc isoconcentration (\%) in loose deposits; $6-$ isoconcentration of lead (\%) in loose deposits; 7 - silver isoconcentration (\%) in loose deposits; 8 - contour of aureoles

Manifestations 19, 20, 22. Deposits and crusts of malachite and azurite are in the schist andesitic porphyrites of the Lower Devonian. The copper content reaches $0.25-1.0 \%$; silver $4.0-100 \mathrm{~g} / \mathrm{t}$; gold $-0.3 \mathrm{~g} / \mathrm{t}$.

Manifestation 23, 24. Smears of malachite and azurite are in silicified and chloritized tuff sandstones of the Lower Devonian. The copper content is up to $0.1-1.0 \%$; silver - up to $1.0-40.0 \mathrm{~g} / \mathrm{t}$.

The Keregetas section is located on the tectonic contact of the Ordovician porphyrites and the terrigenous sedimentary thickness of the Devonian.

Manifestation 29. Northwest Keregetas (Fig. 7). In the silicified and epidotized porphyrites of the Semizbuginsky Formation of the Lower Devonian and their tuffs, two bodies with streaked quartz with deposits and small nests of malachite are crossed by a ditch; ore bodies are 21.5 and $6.0 \mathrm{~m}$ thick with the copper content of 0.15 and $1.48 \%$; silver -1.5 and $50.0 \mathrm{~g} / \mathrm{t}$; gold - up to $2.0 \mathrm{~g} / \mathrm{t}$.

Manifestations 30, 31. In the silicified porphyrites of Ordovician, the copper content of 0.15 and $0.87 \%$ was established by furrow testing; silver $-1.0-5.0 \mathrm{~g} / \mathrm{t}$.

The southern aureoles (Fig. 8) are located southwest of the Keregetas section and are localized in the endo- and exocontact zones of the Carboniferous intrusion and the Ordovician sedimentary-volcanogenic formations.

Manifestation 32. In the schistosized quartz andesite porphyrites of Ordovician, there are small stockwork bodies, in the quartz veins of which crusts and small nests of malachite and azurite are developed. The copper content in the ore sample is $0.4 \%$; gold $-0.02 \mathrm{~g} / \mathrm{t}$.

Manifestation 33. Breakups of a quartz vein with smears of malachite and veined pyrite among andesite porphyrites of Ordovician. The vein parameters are not set. The copper content is $0.2 \%$.

Manifestation 34. Quartz stockwork is in a dyke of granite porphyry, breaking through siliceous siltstones of Ordovician. The length of the dike in the north-western direction is $250 \mathrm{~m}$, the apparent thickness is $5-10 \mathrm{~cm}$. In quartz veins there are deposits of malachite and azurite. The copper content in quartz is $0.5 \%$; silver $-3.0 \mathrm{~g} / \mathrm{t}$ (grab sample, spectral analysis).

Manifestation 35. A dyke of diorite porphyrites with uncertain parameters among the lower carbon granodiorites. Diorite porphyrites are intensely silicified and epidotized with the copper content of up to $0.5 \%$, silver $-1.0 \mathrm{~g} / \mathrm{t}$ (grab sample, spectral analysis).

Manifestation 36. In siliceous siltstones of Ordovician penetrated by veins of quartz, the gold content is $0.05 \mathrm{~g} / \mathrm{t}$; silver $1.0 \mathrm{~g} / \mathrm{t}$. The area parameters are not defined.

Manifestation 37. In siliceous siltstones of the Ordovicahornfelsed in the exocontact zone of the small intrusion of early Carboniferous granodiorites and bearing veinlets of quartz, the copper content of $0.5 \%$ was established by spectral analysis of the grab sample; and gold $-0.02 \mathrm{~g} / \mathrm{t}$.

Conclusions. In the Koktaszhal ore field the oxidation zone and the zone of primary sulfide ores are clearly distinguished. Mineralization is of the stringer-porphyry nature. In Karadok rocks, copper mineralization is developed only in the areas near the contact and intrusion penetrated by a dense network of differently oriented quartz veins. The ores are represented by quartz-chalcopyrite, quartz-chalcopyrite-bornite, chalcopyrite, chalcopyrite-bornite, bornite-malachite,

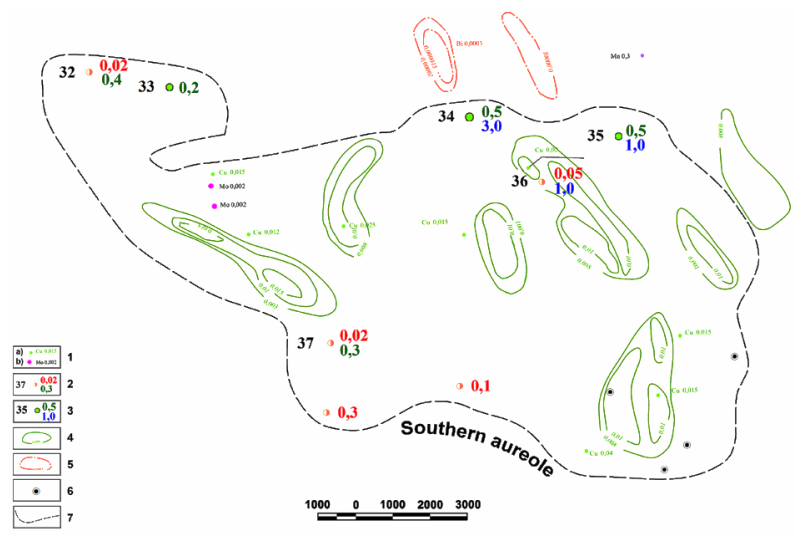

Fig. 8. The pattern of the South aureoles:

1 - samples with the maximum element content; 2 - gold ore occurrence: the figure on the left is the number, the figure on the right is the content: red - gold $(g / t)$, green - copper (\%), blue - silver $(\mathrm{g} / \mathrm{t}) ; 3$ - the same, copper; 4 - isoconcentration of copper (\%) in loose deposits; 5 - isoconcentration of bismuth (\%) in loose deposits; 6 - point with hypergenic copper mineralization (malachite, chrysocolla, azurite); 7 - contour of the aureoles 
chalcopyrite-malachite mineral types, veined, streaky and stringer-porphyry textures. The texture-mineralogical types of ores do not have clear geological boundaries between themselves, and can be identified visually or under a microscope. The streaky ores are predominantly developed; the veined ores are less developed. By technological features, the ores are divided into oxide and sulfide, mixed ores are practically absent.

The analysis of the results of geological exploration carried out within the Koktaszhal ore field allows concluding that mineralization is significant in depth and area and can be of a commercial interest due to the high contents of copper, gold, and silver.

\section{References.}

1. Seitmuratova, E. Yu. (2019). Comments on the current state of the mineral-crystalline base of Kazakhstan and ways to strengthen it. Geology and Mineral Protection, 1(70), 12-17. Retrieved from https://elibrary.ru/item.asp?id=37167293.

2. Ermolov, P.V., Malchenko, E. G., Portnov, V.S., \& Makat, D. K. (2017). A new method for in-depth forecasting of porphyry copper deposits in Central Kazakhstan. International scientific-practical conference "Innovative and promising technologies for exploration in Kazakhstan”, (pp. 50-55). Retrieved from http://repository.kstu.kz/xmlui/bitstream/handle/1234 $56789 / 5839 / \%$ d0\%a2\%d $1 \% 80 \%$ d $1 \% 83 \%$ d0\%b4\%d $1 \%$ $\underline{8 b \% 202 . p d f ? \text { sequence }=1 \& \text { isAllowed }=\mathrm{y}}$.

3. Los, V.L., \& Murzadilov, T.D. (2018). The concept and methodology of the new technological "mainstream". Geology and protection of the bow, 3(68), 58-67. Retrieved from https://elibrary.ru/item.asp?id=35646450.

4. Arndt, N., Kesler, S., \& Ganino, S. (2015). Classification, distribution and use of ore and ore deposits. Metals and society, 15-40. https://doi.org/10.1007/978-3-319-172323 2 .

5. The Code of the Republic of Kazakhstan "On Subsoil and Subsoil Use" (2020). Retrieved from http://adilet.zan.kz/rus/ docs/K1700000125.

6. Roonwal, G.S. (2018). The Search for Ore Deposits and Chances of Success. Mineral Exploration: Practical Application. Singapore: Springer. https://doi.org/10.1007/978-98110-5604-8 3.

7. Bustillo Revuelta, M. (2018). Mineral Deposits: Types and Geology. Mineralresources, 49-119. https://doi.org/10.1007/9783-319-58760-8 2.

8. Duzhnikova, Ye.V., Kryazheva, T.V., \& Kenzhin, B.M. (2019). The mineral composition of the ores and the conditions of their formation at the Koktaszhal deposit. Bulletin of the East Kazakhstan State Technical University named after D. Serikbayev, 1(83), 3-8.

9. Duzhnikova, Ye. V. (2019). Assessment of promising areas of the Koktaszhalore field. Problems of geology and subsoil development, 1, 151-153.

10. Cuney, M. (2018). Ore deposits. Encyclopedia of Geochemistry. Springer, Cham. https://doi.org/10.1007/978-3-31939312-4 126.

\section{Результати досліджень Коктасжальського рудного поля (Центральний Казахстан)}

\section{К. В. Дужнікова, Т. В. Кряжева, К. С. Толеубек}

Карагандинський державний технічний університет, м. Караганда, Республіка Казахстан, e-mail: dizarika1@ gmail.com

Мета. Прогнозна оцінка перспективних точок мінералізації та рудопроявлень міді, золота, срібла й попутних компонентів на Коктасжальському рудному полі.

Методика. Аналіз літературних і фондових матеріалів. Рекогносцирувальні маршрути для дослідження геоло- гічної ситуації району. Під час проходження маршрутів були відібрані проби, проведене їх мінералогічне дослідження для визначення закономірностей розподілу основних рудних мінералів і домішок. Для визначення вмісту корисних компонентів використовувався фазовий хімічний аналіз, спектральний аналіз, спектрозолотометрія.

Результати. Матеріали та їх аналіз, отримані в результаті досліджень, істотно розширюють уявлення про досліджуване рудне поле. Основними рудоутворюючими мінералами є халькопірит і борніт, у значно менших кількостях у рудах присутні халькозин, пірит, молібденіт. Основними окисленими мінералами міді в порядку убування є малахіт, хризоколла, Халькантит, азурит. Завдяки детальним геологічним, мінералого-петрографічним, лабораторним дослідженням були виділені перспективні мідно-порфірові рудопроявлення. Просторово об'єднані та складені схеми ореолів із відображенням на них концентрацій корисних копалин, що рекомендується вивчити більш детально.

Наукова новизна. За результатами досліджень і аналізів були виділені нові перспективні точки мінералізації та зруденіння з використанням новітніх високоточних методів вивчення рудоутворюючих мінералів мідно-порфірових родовищ.

Практична значимість. Дослідження мінералогії рудного поля дозволяє визначити типоморфні особливості мінералів для пошуків і оцінки родовищ корисних копалин та для поліпшення комплексності використання сировини. Використання мінералогічних методів досліджень на сучасному рівні підвищує ефективність геологорозвідувальних робіт, сприяє пошуку нових перспективних площ і родовищ і в цілому збільшення мінерально-сировинної бази Казахстану, шо є однією з найважливіших задач країн, що розвиваються. Результати проведених досліджень можуть служити основою для подальшого довивчення рудного поля, кількісної оцінки перспектив ресурсів, вибору методу відпрацювання та збагачення. Довивчення маловідомих мідно-порфірових рудопроявлень, пошуки нових родовищ міді, золота, срібла й супутніх компонентів є першочерговим завданням їх промислового освоєння в умовах сучасних технологій.

Ключові слова: Коктасжальське рудне поле, мідно-порфірові зруденіння, мінералогічна зональність, Центральний Казахстан

\section{Результаты исследований Коктасжальского рудного поля (Центральный Казахстан)}

\section{Е. В. Дужникова, Т. В. Кряжева, К. Е. Толеубек}

Карагандинский государственный технический университет, г. Караганда, Республика Казахстан, e-mail: dizarika1@gmail.com

Цель. Прогнозная оценка перспективных точек минерализации и рудопроявлений меди, золота, серебра и попутных компонентов на Коктасжальском рудном поле.

Методика. Анализ литературных и фондовых материалов. Рекогносцировочные маршруты для исследования геологической ситуации района. Во время прохождения маршрутов были отобраны пробы, проведено их минералогическое исследование для определения закономерностей распределения основных рудных минералов и примесей. Для определения содержаний полезных компонентов использовался фазовый химический анализ, спектральный анализ, спектрозолотометрия.

Результаты. Материалы и их анализ, полученные в результате исследований, существенно расширяют 
представление об исследуемом рудном поле. Основными рудообразующими минералами являются халькопирит и борнит, в значительно меньших количествах в рудах присутствуют халькозин, пирит, молибденит. Основными окисленными минералами меди в порядке убывания являются малахит, хризоколла, халькантит, азурит. Благодаря детальным геологическим, минералого-петрографическим, лабораторным исследованиям были выделены перспективные медно-порфировые рудопроявления. Пространственно объединены и составлены схемы ореолов с отображением на них концентраций полезных ископаемых, которые рекомендуется изучить более детально.

Научная новизна. По результатам исследований и анализов были выделены новые перспективные точки минерализации и оруденения с использованием новейших высокоточных методов изучения рудообразующих минералов медно-порфировых месторождений.

Практическая значимость. Исследование минералогии рудного поля позволяет определить типоморфные особенности минералов для поисков и оценки месторождений полезных ископаемых и для улучшения ком- плексности использования сырья. Использование минералогических методов исследований на современном уровне повышает эффективность геологоразведочных работ, способствует поиску новых перспективных площадей и месторождений и в целом увеличению минерально-сырьевой базы Казахстана, что является одной из важнейших задач развивающихся стран. Результаты проведенных исследований могут служить основой для последующего доизучения рудного поля, количественной оценки перспектив ресурсов, выбора метода отработки и обогащения. Доизучение малоизвестных медно-порфировых рудопроявлений, поиски новых месторождений меди, золота, серебра и попутных компонентов являются первоочередной задачей их промышленного освоения в условиях современных технологий.

Ключевые слова: Коктасжальское рудное поле, меднопорфировые оруденения, минералогическая зональность, Центральный Казахстан

Recommended for publication by D. Yu. Pak. The manuscript was submitted 11.09.19. 